GDK: 811.4:553+563:111:174.7 Pinus nigra(045)=111

Prispelo / Received: 03. 12. 2012

Sprejeto / Accepted: 28. 12. 2012

Izvirni znanstveni članek

Original scientific paper

\title{
MULTIPLE TREE-RING PARAMETERS FROM Pinus nigra (ARNOLD) AND THEIR CLIMATE SIGNAL
}

Simon POLJANŠEK ${ }^{1}$, Tom LEVANIČ²

\begin{abstract}
The first exploration of climate signal in tree-rings of Black pine ( $P$. nigra Arnold), using minimum blue intensity method, is presented. Sampled trees were growing on site Kojnik (Slovenia). For resin extraction and scanning, $5 \mathrm{~mm}$ thick cores were prepared. Whole tree-ring widths were measured, as well as the width and density of early- and latewood. To remove age trend and influence of non-climatic factors, raw measurements were standardized using spline function. In density measurements, highly significant correlation values were calculated between May-June summed precipitation and earlywood density ( $\mathrm{r}=$ $0.64, p<0.001)$, while maximum latewood density correlates the best with mean June-August temperature $(r=0.42, p<0.01)$. In width measurements, the highest correlation was calculated between tree-ring width and mean June-August temperature $(\mathrm{r}=-0.62, \mathrm{p}<0.001)$.
\end{abstract}

Key words: minimum blue intensity, Black pine, Kojnik, sub-Mediterranean, drought, response, density

\section{PARAMETRI BRANIK DREVES Pinus nigra (Arnold) IN NJIHOV KLIMATSKI SIGNAL}

\section{Izvleček}

Predstavljamo prvo analizo klimatskega signala v branikah črnega bora (P. nigra Arnold) s pomočjo metode odboja modrega spektra. Izbrana drevesa so rastla na Kojniku. Iz vzorcev debeline $5 \mathrm{~mm}$ smo ekstrahirali smolo in jih optično skenirali. Izmerili smo širino celotne branike ter širino in gostoto ranega ter kasnega lesa. Za odstranitev starostnega trenda in drugih ne-klimatskih faktorjev smo merjene časovne serije standardizirali s kubičnim zlepkom. Pri meritvah gostot smo značilne korelacije izračunali med padavinami obdobja maj-junij ter gostoto ranega lesa $(r=0.64, p<0.001)$, medtem ko je gostota kasnega lesa $v$ najboljši korelaciji s povprečno temperaturo obdobja junij-avgust $(r=0.42, p<0.01)$. Pri merjenju širin je bila najvišja korelacija med širino celotne branike in povprečno temperaturo obdobja junij-avgust $(r=-0.62, p<0.001)$.

Ključne besede: metoda odboja modrega spektra, črni bor, Kojnik, sub-mediteran, suša, odziv, gostota

\section{INTRODUCTION UVOD}

Morphological properties of newly developed xylem cells, which define tree-ring characteristics, are influenced by the length of growing season, the growth and speed-rate of cell division and environmental factors (Gričar and Čufar, 2008; Levanič, 1993). The influence of climate on tree growth can be studied using measurements of various tree-ring characteristics; whole tree-ring width (TRW), early / latewood width (EWW / LWW), and tree-ring density. Densitometry is a process in which we obtain measurements of wood density within the tree-ring (Fritts, 1976). Density characteristics of conifer tree-rings were originally studied using X-rays (Parker et al., 1980; Parker et al., 1976; Polge, 1963; Schweingruber et al., 1978), although X-rays had been used even earlier in various qualitative wood evaluation examinations (Tomazello et al., 2008). X-ray densitometry is expensive and it requests under the right angle oriented fibres (Schweingruber et al., 1978), so efforts have been made to develop alternative paleoclimate proxies, which are as reliable as the $\mathrm{X}$-ray densitometry, but can be applied more readily and efficiently. Method of minimum blue intensity, also named minimum blue reflection (MBR), requires no specific equipment other than a Soxhlet extractor, high-quality colour scanner, a personal computer and an appropriate software (McCarroll et al., 2002). Developers assessed the suitability of multiband digital images (RGB) of Scots pine (Pinus sylvestris L.) laths as a surrogate for X-ray densitometry. The blue channel proved to correlate most strongly $(r=-0.96)$ with maximum latewood density (MXD), measured using optical Walesch 2002 microdensitometer (McCarrol et al., 2002). Intensity of this channel is sensitive to the amount of lignin present; when illuminated by short-wavelength light, the lignin absorbs most of the energy and the light energy absorbed by lignin declines as wavelength increases (McCarroll et al., 2002). However,

\footnotetext{
${ }^{1}$ S. P., univ. dipl. inž. gozd., Gozdarski inštitut Slovenije, Večna pot 2,1000 Ljubljana, simon.poljansek@gozdis.si

${ }^{2}$ doc. dr. T. L., univ. dipl. inž. gozd., Gozdarski inštitut Slovenije, Večna pot 2,1000 Ljubljana, tom.levanic@gozdis.si
} 
the measured tree-ring density represents only the proxy for wood density; these values have not been calibrated.

With densitometry, scientists discovered, at some sites, even stronger relationship between climate and tree-ring density than between climate and tree-ring widths (Cown and Parker, 1978; Levanič et al., 2008; Schweingruber et al., 1978). This is the case of researching on more moist, complacent sites, where the rings may be wide and the widths may exhibit much less variability than wood density characteristics, or in the high latitudes, where MXD is a better indicator of summer temperature than tree-ring width (Kirdyanov et al., 2007). In areas of little width variation, dendroecology may be possible only because of the greater variability in density measurements (Fritts and Swetnam, 1998). In reconstructing climate, some report that it is the MXD that has proved to be the best surrogate for climate (Campbell et al., 2007; McCarroll et al., 2002), while other claim that tree-ring parameters beside TRW reveal little additional potential (Esper et al., 2006). Blue intensity was introduced and tested on $P$. sylvestris, but for a general usage it needs to be tested on other paleoclimatologically important conifers. One of them is $P$. nigra (Arnold) (Levanič et al., 2012; Nicault et al., 2008). X-ray densitometry on $P$. nigra in Spain revealed small MXD inter-series correlations and thus a lower common variance; furthermore, MXD on P. nigra does not correlate significantly with climate from previous or current year of growth (Dorado Liñán et al., 2012). Testing MBR on Atlas cedar (Cedrus atlantica) showed that MXD contains low common variance and weak climatic signal, comparing to TRW, but it was the minimum density (earlywood density), which seems to provide additional information on past precipitation (Esper et al., 2006). For this reason, climate signal in density of $P$. nigra tree-ring parameters was tested and results compared to width measurements of earlywood, latewood and total tree-rings.

The aims of this study are to:

- Explore potential of minimum blue reflectance (MBR) on P. nigra in Slovenian sub-Mediterranean region,

- identify climate signal in tree-ring parameters, and to

- compare climate signal in multiple tree-ring parameters

\section{MATERIALS AND METHODS MATERIALI IN METODE}

\section{SPECIES SELECTION, SITE DESCRIPTION AND CLIMATE DATA IZBIRA DREVESNE VRSTE, OPIS RASTIŠČA IN
KLIMATSKI PODATKI}

P. nigra is a widespread species in the Mediterranean area and it grows on a wide altitudinal range from 500 to $2,000 \mathrm{~m}$ a.s.l. (Vidaković, 1991). In Slovenia, P. nigra is widely dispersed and can be found on southern slopes of the Kolpa River valley, in the Iška gorge, above the Gorenja Trebuša valley, on the slopes of Jerebica and Mangart, above the Tolmin$\mathrm{ka}$ and in some parts of the Karavanke Mts (Brus, 2004), as well as in the Kras region, where the barren karst areas were afforested with P. nigra in the late $18^{\text {th }}$ century (Kranjc, 2009). It can grow on extreme sites, where missing rings (Wilmking et al., 2012) can occur (Figure 2). Trees, growing on extreme sites, are suitable for investigation of climatological questions related to tree growth (Fritts, 1976). Trees were sampled in a stand on Kojnik hill (780 m a.s.1.) in sub-Mediterranean Slovenia. The term 'sub-Mediterranean Slovenia' denotes the south-west region of Slovenia, which lies under the Alpi-

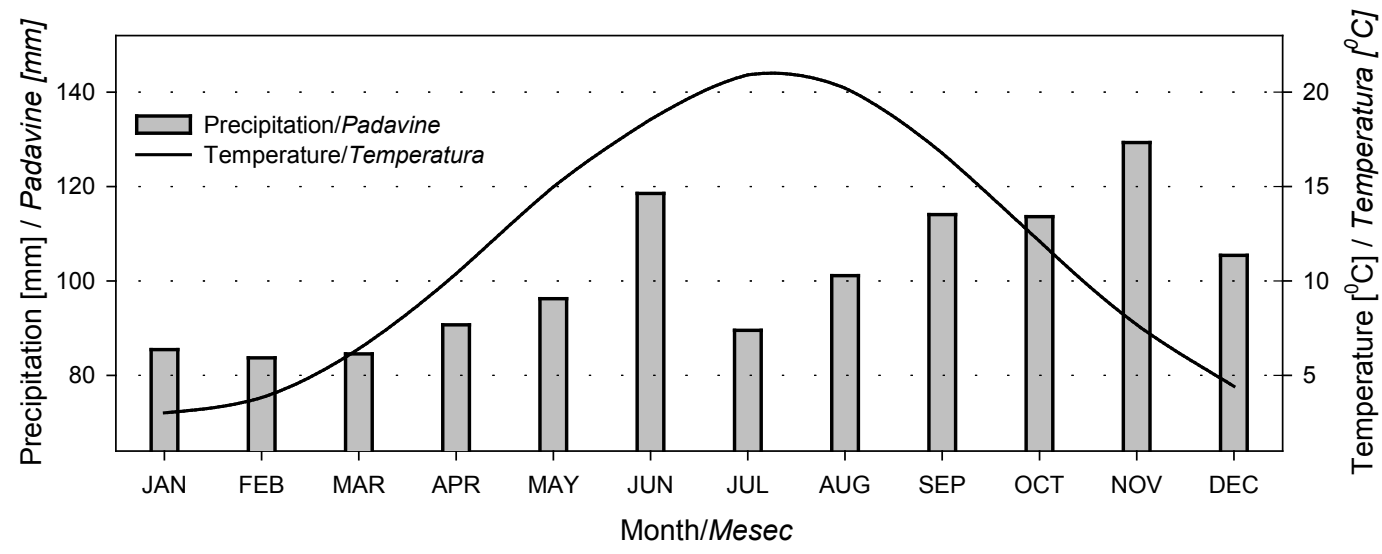

Fig. 1: Long-term average of temperatures and precipitation on monthly basis at Kubed weather station

Slika 1: Dolgoletno merjeno povprečje mesečnih vrednosti temperature in padavin postaje Kubed 
ne-Dinaric barrier and opens towards the Adriatic Sea, from which the forests grow under the influence of Mediterranean climate (Ogrin, 2005), although there is no strong seasonality in rainfall distribution (Šraj et al., 2008). The area is characterized by its deficit in humidity, owing to the prevailing karst features of the surface, high temperatures and frequent droughts in the summer months of July and August, causing higher potential evapotranspiration than precipitation in July and August (Ogrin, 2005). Climate influence on P. nigra from the sub-Mediterranean region has already been investigated (Ogrin, 1989; 1992; 2005; Srebotnjak, 1997), using different climate stations. In our case, the Kubed weather station (available data range from 1950 to 1990), supplied by the Slovenian Environment Agency, was used (Figure 1).

\section{SAMPLE PREPARATION AND MEASUREMENTS PRIPRAVA VZORCEV IN MERITVE}

This investigation was aimed at testing blue reflectance on P. nigra, and for this purpose only ten trees were sampled, using $5 \mathrm{~mm}$ increment borer. From $1.3 \mathrm{~m}$ height, two cores from the opposite sites of the stem were taken perpendicular to the slope, to avoid compression wood, which would influence density measurements. Fresh cores were marked on a side with wood burning pen (pyrography) and put into Soxhlet apparatus to extract resin. Resin extraction was done at the Biotechnical Faculty, Department of Wood Science and
Technology. Cores in Soxhlet were treated with 3 liquids in three cycles, each time for 24 hours: first with mixture of nhexane / ethanol $100 \%$ (2:1 ratio), second $100 \%$ ethanol and third with $100 \%$ distilled water. Our method was modified from originally suggested 30-40 hours of refluxing in ethanol (Campbell et al., 2011). After the laboratory procedure, cores were relocated to the dendrochronological laboratory of the Department of Yield and Silviculture at the Slovenian Forestry Institute. Samples were air dried, fixed on holders and sanded with progressively smoother sanding paper, until high polish surface was achieved. Sample scanning was carried out at the University of Swansea, Geography Department Laboratory, on Epson Expression 1680 flatbed Pro Series scanner. For the blue reflectance measurement, a colour card with steps of known blue intensity is used to remove age and power intensity effect of scanner bulbs and to ensure comparability of blue intensity values measured at different times or with different equipment (Campbell et al., 2011). We used Monaco EZ-colour card (monr2004:08-01 version 2) for light calibration. Originally, 1000 dpi scanning was suggested (Campbell et al., 2011), although even at the modest scanning resolution used, the technique yielded reliable results (McCarroll et al., 2002). But results on P. abies showed more pronounced latewood peaks at 1200 dpi (Babst et al., 2009), and as there were some thoughts on using $1200 \mathrm{dpi}$ on very narrow rings of climatically sensitive trees (Babst et al., 2009), we decided to use 1600 dpi. Scanning resolution affec-

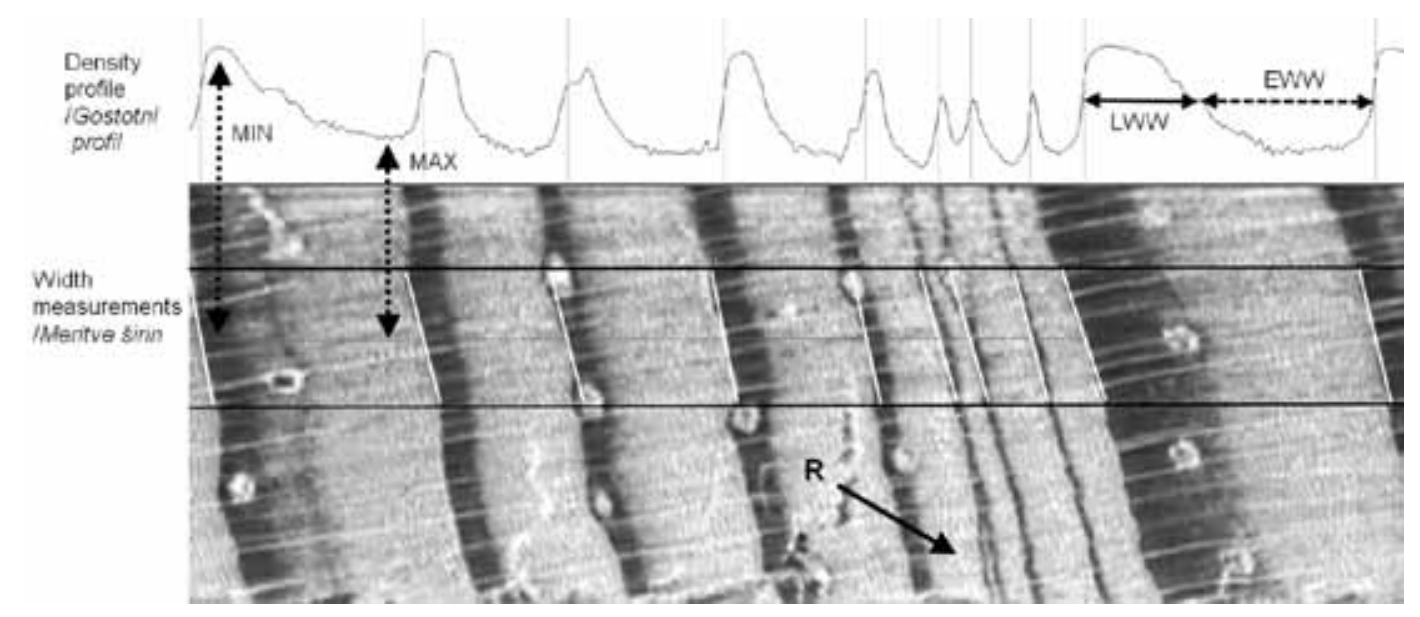

Fig. 2: Density profile and width measurements in WinDENDRO ${ }^{\text {TM}}$; MIN marks the minimum blue reflectance and the maximum latewood density, MAX the maximum reflectance from earlywood and the minimum earlywood density, while LWW, EWW denote latewood, earlywood width, respectively. Solid arrow, marked with R, points at the "missing ring"

Slika 2: Gostotni profil in meritve širin branik v programu WinDENDRO svetlobe in hkrati točko maksimalne gostote kasnega lesa, MAX označuje maksimalni odboj modre svetlobe od ranega lesa oziroma minimalno gostoto ranega lesa, medtem ko LWW in EWW označujeta širino kasnega in ranega lesa, $v$ tem zaporedju. Polna puščica, označena s črko R, označuje mesto izklinjene branike 
ts the density results. This is noticeable if the scanning resolution is increased to $2600 \mathrm{dpi}$, which is above the hardware resolution of the device, then there is a strong shift towards less intensity and the peaks of the latewood even reached a BR of zero (Babst et al., 2009). Samples were saved as 24bit colour images in TIFF (Tagged Information File Format). Produced images were analysed using commercially available software WinDENDRO ${ }^{\mathrm{TM}}$ for Densities software (www. regentinstruments.com). Brighter part of the image is found in the earlywood, where less dense wood is placed and the light reflectance is higher, while the darker part is in latewood, where MXD is (Figure 2). Values of MBR actually represent amount of light reflected from the sample. From this point on, MAX / MIN will denote the intensity of the light, reflected from the sample; MAX represents maximum amount of reflected light (regularly in earlywood) and MIN minimum amount of reflected light (regularly in latewood). MIN values are, therefore, a proxy record for MXD. The WinDENDRO ${ }^{\mathrm{TM}}$ for Densities software enables measuring widths and densities of earlywood, latewood and whole tree-ring. The width of each annual ring was measured to the nearest $0.01 \mathrm{~mm}$ and the border between early and latewood was set at $50 \%$ of the density profile.

\section{STATISTICAL ANALYSIS}

\section{STATISTIČNA ANALIZA}

Crossdating and synchronization of tree-ring time-series was done in PAST-4 ${ }^{\mathrm{TM}}$ software (www.sciem.com), using visual comparison and statistical coefficients $t_{B P}$ (Baillie and Pilcher, 1973) and GLK\% (Eckstein and Bauch, 1969). GLK\% measures the year-to-year agreement between the interval trends of two time series, based upon the sign of agreement and expressed as percentage. Coefficient $t_{\mathrm{BP}}$ determines the correlation between two time series. To remove longterm trends (Cook, 1985), all individual proxy series were standardized using $67 \%$ cubic smoothing spline (Cedilnik, 1991) with a $50 \%$ frequency cut-off and all basic statistical parameters of proxies were calculated in ARSTAN for Windows, version 4.1d, program provided by Cook and Krusic, Lamonth-Doherty Earth Observatory, Columbia University (http://www.ldeo.columbia.edu/trl). Each year's proxy value was divided by the year's value of the fitted curve to give a dimensionless index with a mean of 1 . This was done to remove non-climatic trends due to the tree age, size and the effects of stand dynamics (Cook and Kairiukstis, 1990). MIN has low values of autocorrelation and, for this reason, some authors do not apply standardization to raw chronologies (Kirdyanov et al., 2007), while others use negative exponential or linear equation (Campbell et al., 2007). Index values were then prewhitened using an autoregressive model selected on the basis of the minimum Akaike criterion and combined across all series using biweight robust estimation of the mean to exclude the influence of the outliers. This way standardized chronology was produced (Cook, 1985; Cook and Kairiukstis, 1990). Expressed population signal (EPS) and sensitivity analysis were also calculated; A series with EPS threshold of at least 0.85 (Briffa and Jones, 1990) and 0.2 of mean sensitivity (Speer, 2010) is normally regarded as a series that is sensitive enough for climate reconstruction. Sensitivity is a measure of a relative difference in proxy value between two adjacent tree-rings; the values of mean sensitivity range from 0 , where there is no difference to 2 , where a zero value occurs next to a nonzero one in the time sequence (Fritts, 1976). Finally, the Pearson correlation coefficient (r value) was calculated between climate data and proxy data.

\section{RESULTS} REZULTATI

\section{STANDARDIZED CHRONOLOGIES STANDARDNE KRONOLOGIJE}

Selected trees were from 51 to 95 years old, with an average of 86 years (Table 1). The terminal-ring was formed in the year 2011, while the oldest tree-ring was dated in the year 1917. Variability of tree-ring parameters, measured in standard deviation (SD), was the highest in LWW (0.57). Very similar SD values were in TRW, EWW and MIN (from 0.34 to 0.35). Average sensitivity reached threshold values in all series, except MAX; the highest was calculated in latewood widths (average 0.45 ) and the lowest in MAX reflectance (average 0.06).

In the standardization process, the abnormal standardized values at the end of TRW, LWW and EWW chronology were observed in trees 2, 3, 4, 7, 8 and 10. Unusually high values of the years 2010 and 2011 are the mathematical fault; In the process of dividing measured values with expected values of below $0.5 \mathrm{~mm}$, the function of dividing transforms into multiplying, causing higher than measured values. Other problems of the so-called end-effect in standardization and how to avoid them are beyond the scope of this paper and are described elsewhere (Esper et al., 2006; Melvin and Briffa, 2008). As 
Table 1: $\quad$ General statistics of whole tree-ring width (TRW), earlywood width (EWW), latewood width (EWW), maximum reflectance (MAX) and minimum reflectance (MIN) standardized (STD) chronologies, with data on standard deviation (SD), mean sensitivity (MS) and autocorrelation coefficient (AC) for each of the individual standardized tree-ring indices and the mean

Preglednica 1: Statistični kazalci standardnih (STD) kronologij celotne širine branik (TRW), širine ranega lesa (EWW), kasnega lesa (LWW), maksimalnega odboja (MAX) in minimalnega odboja (MIN), s podatki o standardnem odklonu (SD), srednji stopnji občutljivosti (MS) in avtokorelacijskem količniku (AC) za vsako od individualnih oziroma za povprečno standardno kronologijo (mean)

\begin{tabular}{|c|c|c|c|c|c|c|c|}
\hline \multicolumn{3}{|c|}{ STD chronology of: } & \multirow{2}{*}{$\begin{array}{c}\text { TRW } \\
\text { SD/MS/AC }\end{array}$} & \multirow{2}{*}{$\begin{array}{c}\text { EWW } \\
\text { SD/MS/AC }\end{array}$} & \multirow{2}{*}{$\begin{array}{c}\text { LWW } \\
\text { SD/MS/AC }\end{array}$} & \multirow{2}{*}{$\begin{array}{c}\text { MAX } \\
\text { SD/MS/AC }\end{array}$} & \multirow{2}{*}{$\begin{array}{c}\text { MIN } \\
\text { SD/MS/AC }\end{array}$} \\
\hline $\mathrm{n}$ & Period/Obdobje & Years / Leta & & & & & \\
\hline 1 & $1961-2011$ & 51 & $0.25 / 0.27 / 0.22$ & $0.26 / 0.28 / 0.16$ & $0.39 / 0.47 / 0.08$ & $0.08 / 0.08 / 0.09$ & $0.27 / 0.23 / 0.18$ \\
\hline 2 & $1925-2011$ & 87 & $0.35 / 0.29 / 0.49$ & $0.35 / 0.28 / 0.52$ & $0.45 / 0.43 / 0.32$ & $0.06 / 0.05 / 0.17$ & $0.36 / 0.26 / 0.44$ \\
\hline 3 & $1925-2011$ & 87 & $0.33 / 0.25 / 0.45$ & $0.33 / 0.25 / 0.37$ & $1.33 / 0.45 / 0.51$ & $0.09 / 0.08 / 0.28$ & $0.24 / 0.24 / 0.15$ \\
\hline 4 & $1919-2011$ & 93 & $0.36 / 0.31 / 0.45$ & $0.32 / 0.29 / 0.35$ & $0.53 / 0.44 / 0.43$ & $0.06 / 0.05 / 0.22$ & $0.31 / 0.24 / 0.39$ \\
\hline 5 & $1917-2011$ & 95 & $0.39 / 0.33 / 0.60$ & $0.38 / 0.35 / 0.53$ & $0.51 / 0.47 / 0.48$ & $0.08 / 0.06 / 0.43$ & $0.39 / 0.27 / 0.41$ \\
\hline 6 & $1922-2011$ & 90 & $0.37 / 0.32 / 0.46$ & $0.36 / 0.34 / 0.32$ & $0.48 / 0.41 / 0.47$ & $0.09 / 0.08 / 0.19$ & $0.29 / 0.23 / 0.40$ \\
\hline 7 & $1921-2011$ & 91 & $0.37 / 0.31 / 0.40$ & $0.35 / 0.31 / 0.34$ & $0.49 / 0.45 / 0.30$ & $0.07 / 0.07 / 0.32$ & $0.45 / 0.31 / 0.49$ \\
\hline 8 & $1920-2011$ & 92 & $0.40 / 0.31 / 0.53$ & $0.39 / 0.30 / 0.51$ & $0.50 / 0.45 / 0.40$ & $0.06 / 0.05 / 0.13$ & $0.51 / 0.31 / 0.62$ \\
\hline 9 & $1924-2011$ & 88 & $0.33 / 0.28 / 0.41$ & $0.34 / 0.29 / 0.41$ & $0.49 / 0.48 / 0.25$ & $0.06 / 0.05 / 0.26$ & $0.28 / 0.25 / 0.20$ \\
\hline \multirow[t]{3}{*}{10} & $1925-2011$ & 87 & $0.39 / 0.29 / 0.50$ & $0.38 / 0.29 / 0.50$ & $0.51 / 0.43 / 0.39$ & $0.08 / 0.06 / 0.40$ & $0.27 / 0.22 / 0.39$ \\
\hline & \multicolumn{2}{|c|}{ Mean/Povprečje } & $0.35 / 0.29 / 0.45$ & $0.35 / 0.30 / 0.40$ & $0.57 / 0.45 / 0.36$ & $0.07 / 0.06 / 0.25$ & $0.34 / 0.26 / 0.37$ \\
\hline & \multicolumn{2}{|c|}{$\mathrm{EPS} \geq 0.85$} & 1937 & 1937 & 1940 & 1967 & 1951 \\
\hline \multicolumn{3}{|c|}{ inter-series correlation / inter-korelacija } & 0.477 & 0.458 & 0.357 & 0.309 & 0.275 \\
\hline
\end{tabular}

there are no climate data from the Kubed weather station after 1990, we simply removed the years 2010 and 2011. For climate influence analysis, only the part of chronologies, where EPS is higher or equal to 0.85 , and without the years after 1990, was used. Observing the plotted raw chronologies of
TRW, EWW and LWW (Figure 3), the highest variability among width parameters is noticed in LWW, and in density in MIN. The lowest variability in standardized chronologies is noticed in MAX, this is confirmed by the mean value of SD (Table 1).

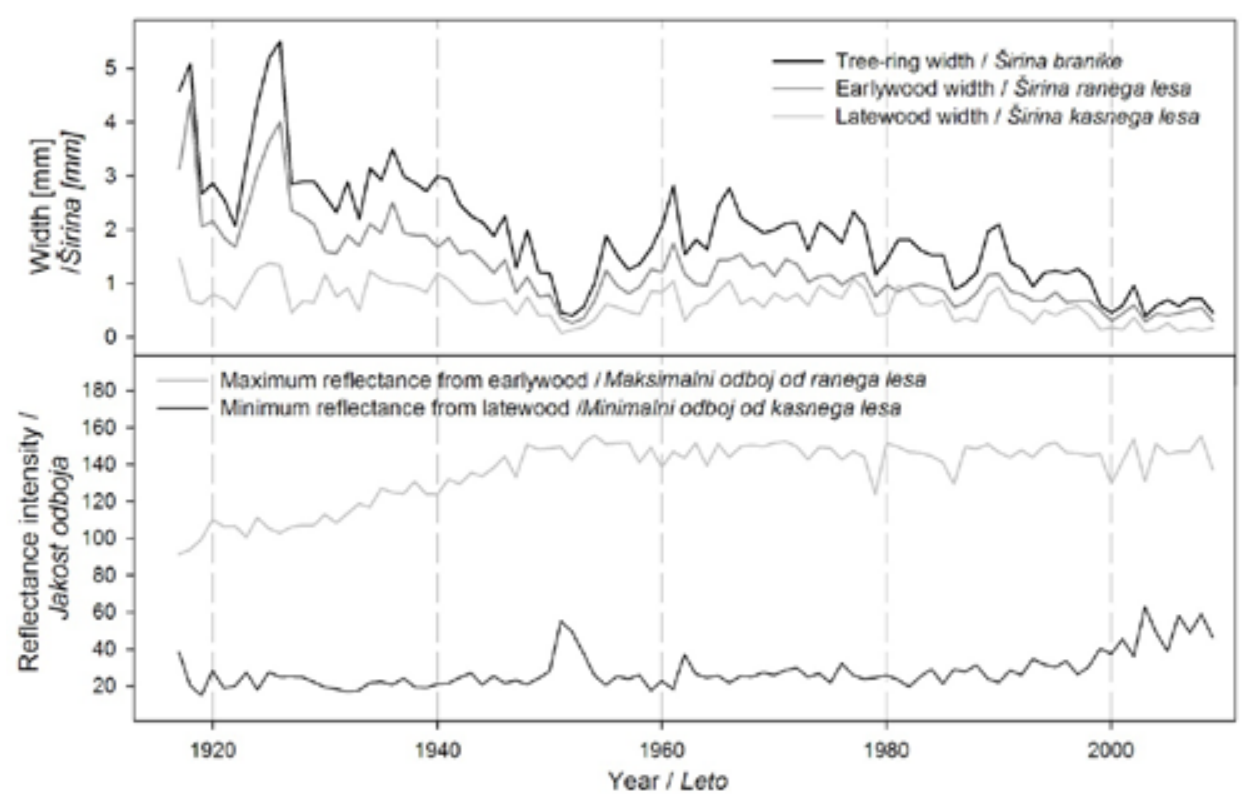

Fig. 3: Raw chronologies of whole tree-ring width, earlywood and latewood in the upper part of the figure, with maximum and minimum blue reflectance in the lower part of the figure

Slika 3: Osnovne kronologije širin branik, širin ranega ter kasnega lesa v zgornjem delu slike in maksimalnega ter minimalnega odboja v spodnjem delu slike 


\section{CLIMATE-TREE GROWTH RELATIONSHIP ODNOS MED KLIMO IN RASTJO DREVES}

Widths of tree-ring parameters (TRW, EWW, LWW) are positively correlated with March temperature and July, August precipitation, and negatively with summer temperatures from July, August and September (Figure 4). This relationship is even stronger, if months are combined into periods.
The highest correlation between width parameters and climate is with June-August mean temperature and the highest individually is found between LWW and August temperature $(\mathrm{r}=-0.60, \mathrm{p}<0.001)$. Precipitation has positive influence on all width parameters in current summer period May-August, with the highest correlations between LWW and August precipitation $(r=0.44)$. For the previous growth year, significant correlations with precipitation were found in EWW; May $(\mathrm{r}=$

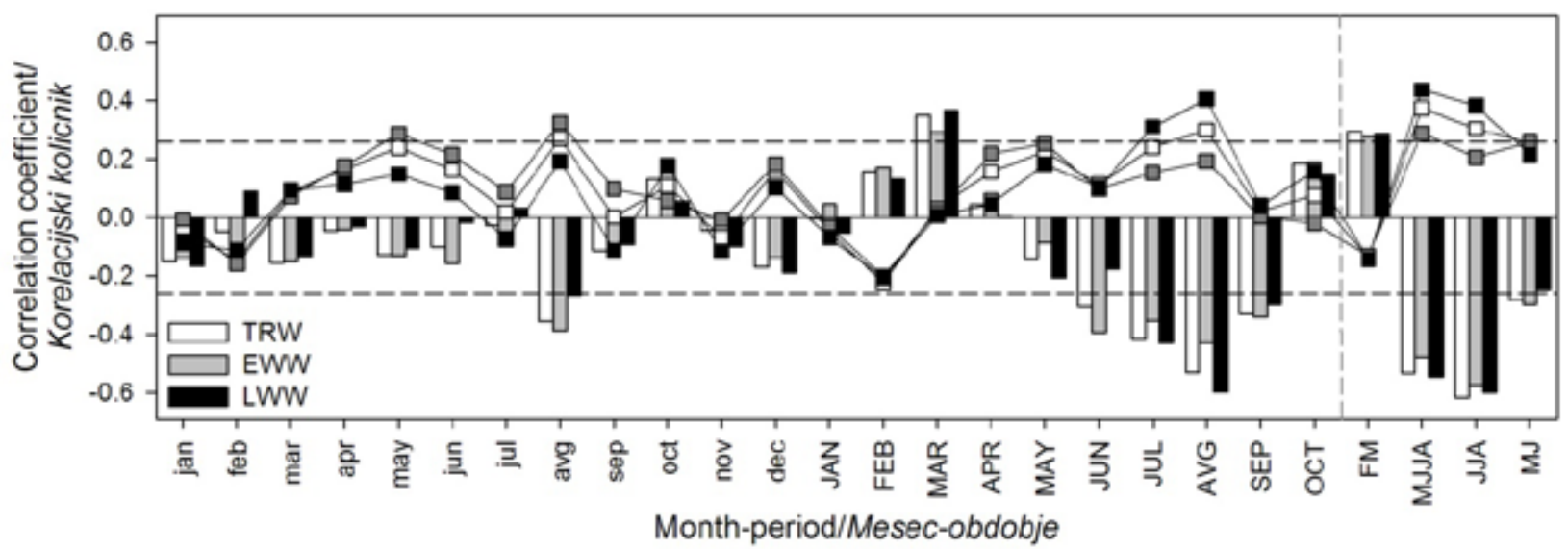

Fig. 4: Correlation coefficients between tree ring width (TRW), earlywood width (EWW), latewood width (LWW) and the climate data; temperatures (columns) and precipitation (lines). Significance is presented with dashed line $(\mathrm{r}=0.26$, $\mathrm{p}=0.05 \%$ ). Values are presented for previous and current years by months and periods (FM; February-March, MJJA; May-August, JJA; June-August, and MJ; May-June)

Slika 4: Korelacijski koeficienti med širino branike (TRW), širino ranega (EWW) ter kasnega lesa (LWW) in klimo; temperaturo (stolpci) ter padavinami (črte). Statistična značilnost je predstavljena s črtkano črto $(r=0,26, p=0,05 \%)$. Vrednosti so predstavljene za preteklo in tekoče leto z meseci ter periodami (FM; februar-marec, MJJA; maj-avgust, JJA; junijavgust, in MJ; maj-junij)

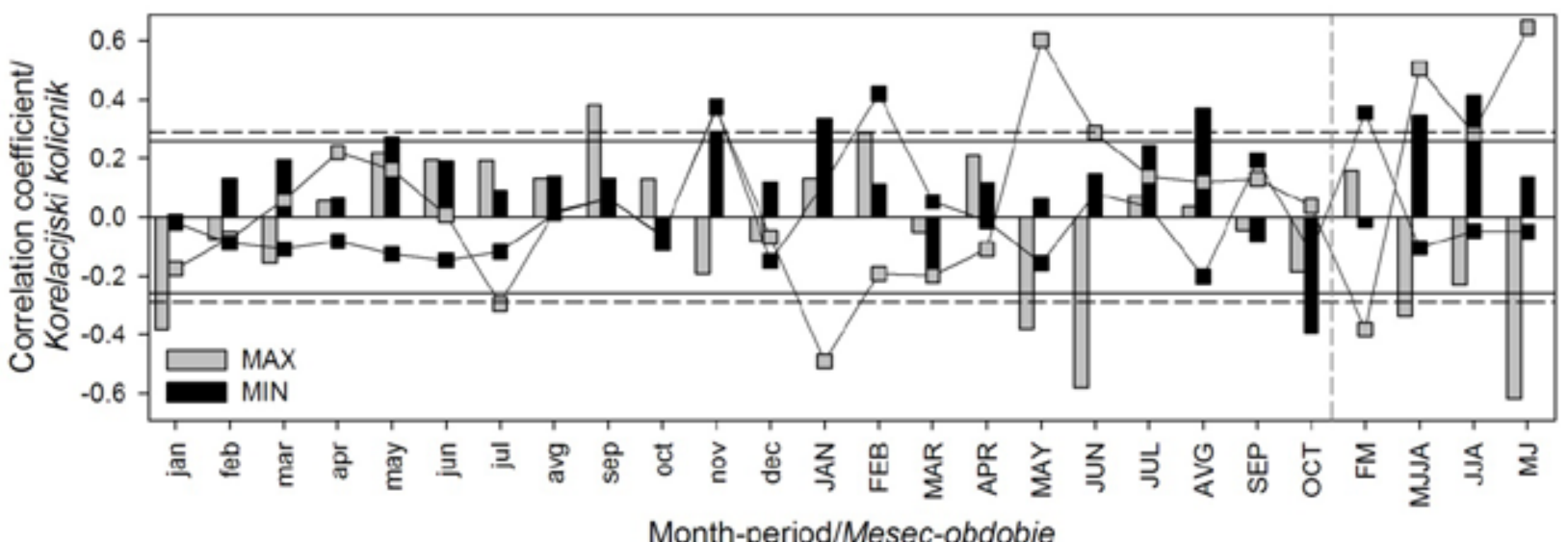

Fig. 5: Correlation coefficients between earlywood density (MAX), latewood density (MIN) and the climate data; temperatures (columns) and precipitation (lines). Significance is presented with solid line $(\mathrm{r}=0.29, \mathrm{p}=0.05 \%)$ for latewood $(\mathrm{MIN})$ and with dashed line $(\mathrm{r}=0.26, \mathrm{p}=0.05 \%)$ for earlywood (MAX). Values are presented for previous and current years by months and periods (FM; February-March, MJJA; May-August, JJA; June-August, and MJ; May-June)

Slika 5: Korelacijski koeficienti med gostoto ranega lesa (MAX) in kasnega lesa (MIN) ter klimo; temperaturo (stolpci) ter padavinami (črte). Statistična značilnost koeficientov korelacij za gostoto kasnega lesa (MIN) je predstavljena s črtkano $\check{c} r$ to $(r=0.29, p=0.05 \%)$, s polno črto $(r=0.26, p=0.05 \%)$ pa statistična značilnost ranega lesa (MAX). Vrednosti so predstavljene za preteklo in tekoče leto z meseci ter periodami (FM; februar-marec, MJJA; maj-avgust, JJA; junijavgust, in MJ; maj-junij) 
$0.29)$ and August $(\mathrm{r}=0.33)$ (Figure 4). In the density measurements, the strongest correlations were found between MAX and June $(\mathrm{r}=-0.58)$ or May-June temperature $(\mathrm{r}=-0.62)$, and precipitation from May $(\mathrm{r}=0.60)$ and May-June period $(\mathrm{r}=0.64)$ (Figure 5). Also, seasonalized precipitation from May-August period significantly correlates with MAX, but this goes more on the account of combining significant May and June precipitation influence with insignificant influence of July and August precipitation. Correlation coefficients between MIN and climate are not that strong - we found the highest correlation with mean June-August temperature, $r=$ 0.42 (Figure 5). While TRW, EWW and LWW have uniform, negative or positive correlation values with temperatures and precipitation (Figure 4), the MAX and MIN have, in the majority of months or periods, opposite values (Figure 5). In measuring the widths, high summer temperatures have a negative influence on the tree-ring, early- and latewood widths, while spring temperatures exert a positive influence. In measuring densities, summer temperatures correlate negatively with MAX (proxy for earlywood density) and positively with MIN (proxy for latewood density). The higher the summer temperatures, the denser the latewood and earlywood.

\section{DISSCUSION}

\section{RAZPRAVA}

In this short investigation, MBR was used on $5 \mathrm{~mm}$ thick cores. Originally, this method was applied on 10 or $12 \mathrm{~mm}$ wide cores (McCarroll et al., 2002). Whether there is a difference in success of resin removal between $5 \mathrm{~mm}$ cores and thin laths, cut out of $10 \mathrm{~mm}$ cores, (Campbell et al., 2011), further tests should be done. In the process of sanding cores, differences in latewood colour between roughly, medium and smoothly sanded samples were noticed. None of the sample surface was burned due to the heat between the sample and the circulating sanding paper, but this influence could be avoided using the core-microtome (Gärtner and Nievergelt, 2010). We are aware that influence of coloured heartwood on reflectance readings is also unknown, so further investigations should be carried out in this direction, as previously suggested by Babst et al. (2009).

Age trend and stand influence were removed from raw chronologies using standardization. In all chronologies, except in MAX, an unusually great growth decline in the 1950-1954 period is observed (Figure 3). The reason could be a forest fire, as the majority of the trees had similar response.
Forest fire already influenced forest in this area in the past (Jurc, 2001). With the length of 95 years, we have developed twice as long P. nigra site chronology, compared to previously published $P$. nigra chronology from sub-Mediterranean Slovenia (Ogrin, 2005), but shorter than developed chronologies from the Divača Komen area (Srebotnjak, 1997). To test reliability of the newly developed Kojnik site chronology, we compared it to the available chronologies, archived at the Slovenian Forestry Institute, Department for Yield and Silviculture. We obtained good results comparing Kojnik chronology to P. nigra chronology from a Croatian site with $7.3 \mathrm{t}_{\mathrm{BP}} / 68.9$ GLK\% (Poljanšek and Levanič, unpublished data), Šipovo and Krivaja chronology from $\mathrm{BiH}$ with $\mathrm{t}_{\mathrm{BP}}>3 / \mathrm{GLK} \%>57$ (Poljanšek S. et al., 2012), and P. heldreichii chronology from $\mathrm{BiH} \mathrm{t}_{\mathrm{BP}}>4.2$ / GLK\% 69.7 (Poljanšek and Levanič, unpublished data). These results confirm transect from $\mathrm{BiH}$ over Croatia towards Slovenia, but for further investigations, a denser dendrochronological network is needed.

All tree-ring parameter chronologies have low EPS values in the beginning of the chronologies (Table 1), which could be the influence of a "juvenile effect". Juvenile wood is relatively thin-walled lignified xylem tissue, which is low in density and is formed in young trees or in tissues located near the stem apex (Fritts, 1976). Its influence is well known for the first 50-100 years in P. nigra tree-ring width, density and stable isotope series (Dorado Liñán et al., 2012), but if trees grow on extreme sites, this juvenile period is shorter (Fritts, 1976). One of the possible reasons for weak signal in MIN could be the influence of the resin ducts, but it is difficult to address influence of resin ducts on MIN variations, as the relatively large intra-tree density variations have been also reported for species, with less resin ducts as $P$. nigra, like balsam fir ( $A b i$ es balsamea) (Koga and Zhang, 2004) and Norway spruce (Picea abies) (Jyske, 2008). In A. balsamea, they discovered that wood density characteristics show remarkably smaller variations, compared to ring width and its components, and that the intra-tree variations in ring width and wood density components are much larger than inter-tree variations (Koga and Zhang, 2004). This is also confirmed by our measurements of MIN and MAX, as their SD values are lower than in width measurements (Table 1). Low inter-series correlation could also be the result of various other factors, such as thinning, crown position, growth rate, fertilization (Jyske, 2008), high between-tree genetic variation (Jyske, 2008), or drought response of individual trees (Martinez-Meier et al., 2008). 


\section{CLIMATE AND TREE-GROWTH} KLIMA IN RAST DREVES

Climate signal in radial increments of $P$. nigra from subMediterranean Slovenia has been previously studied in flysch and karst areas (Ogrin, 2005) and in the Divača Komen karst region (Srebotnjak, 1997). Stimulating effect of above average temperatures at the beginning of the growth period is reported; winter: $r=0.50$; spring: $r=0.29$; March: $r=0.55$ (Ogrin, 2005). From Kojnik site, we also report on significant correlations for spring $(r=0.30, p<0.05)$, and March temperatures $(\mathrm{r}=0.35, \mathrm{p}<0.05)$. The negative impact on $P$. nigra radial growth of the above-average temperatures in summer $(\mathrm{r}=$ -0.39) and during the entire growth period from April through September $(r=-0.48)$ is clear (Ogrin, 2005). We have significantly strong correlation with mean June-August temperature $(r=-0.62, p<0.001)$, while correlation with mean temperature from growth season is the same as previously published (Ogrin, 2005); $-0.49(\mathrm{p}<0.001)$. When mean monthly temperatures exceed values of $20^{\circ} \mathrm{C}$, negative influence of above average temperatures is expected, as this is approximately the temperature for the optimum growth of trees in the moderate vegetation zone (Fritts, 1976). High temperatures are associated with moisture stress, higher evapotranspiration and, if there is absence of precipitation, also with water deficit in photosynthesis (Fritts, 1976). Current year growth is also affected by climate from the previous year(s) (Cook and Kairiukstis, 1990). While Ogrin (2005) reports on negative influence of previous year autumn temperatures (September: $\mathrm{r}=-0.29$; October: $r=-0.30$; November: $r=-0.35$ ), we calculated significant influence only for the August temperature $(r=-0.39$, $\mathrm{p}<0.01)$. Higher autumn temperatures can prolong the formation of tissues, which use up the nutrition reserve prepared for the growth in spring (Fritts, 1976). These results are also observed in Spain, where variables based on ring width correlate well with the previous summer to autumn temperatures (Dorado Liñán et al., 2012). The density response to temperatures is seen in the early summer period for MAX (May; $\mathrm{r}=-0.38$ and June; $\mathrm{r}=-0.58$, both $\mathrm{p}<0.01$ ) and in the late summer period for MIN $(r=-0.42, p<0.01)$. According to the known mechanisms of tree-ring formation and hypotheses of environmental control of tracheid production and maturation, latewood cells are produced, enlarged and thickened during the second part of a growing season (Kirdyanov et al., 2007). In correlation values of MIN, progressively higher influence of temperatures from May till August is observed (Figure 5), but the only significant month is August $(r=-0.37, p<0.05)$, or from June-August period $(\mathrm{r}=-0.42, \mathrm{p}<0.01)$. This result is not in accordance with a study from Spain, where they report that MXD (measured with X-ray densitometry) does not correlate significantly with climate neither in the previous nor current year of growth (Dorado Liñán et al., 2012).

Precipitation influence on width parameters in our study is less involved than temperature influence. From the Divača Komen Karst, response function recognized June precipitation as significantly influencing TRW, EWW and LWW of P. nigra (Srebotnjak, 1997), while Ogrin (2005) reports on correlation coefficients between TRW and precipitation- July: $r=0.30$; September: $r=0.39$; summer: $r=0.32$; growth period: $r=0.37$; and annual amount of precipitation: $r=0.34$. Similar coefficients are calculated in our study, as TRW correlates with summed summer (May-August) precipitation ( $\mathrm{r}=$ $0.38, \mathrm{p}<0.01$ ), and whole growing season (April-September) precipitation $(\mathrm{r}=0.35, \mathrm{p}<0.01)$. In previous research (Ogrin, 1989), when same locations of sampling trees were used, but with the climate stations Kubed and Kozina, higher correlations between TRW and total precipitation in growth period were discovered $(\mathrm{r}=0.64)$, and with temperatures: March $(\mathrm{r}$ $=0.41)$, May $(r=-0.36)$ and August $(r=-0.37)$. In our investigation, the highest correlation with precipitation was found between MAX and May-June summed precipitation ( $\mathrm{r}=0.64$, $\mathrm{p}<0.001)$. This result is similar to climate signal investigation in C. atlantica from Morocco, where the highest correlations were found between MAX and precipitation sums OctoberSeptember $(r=-0.54)$ and December-July $(r=-0.55)$ (Esper et al., 2006). In the event of reconstructing May-June precipitation using our MAX measurements, there would be a problem; although this is the strongest correlation discovered in our investigation, it would be in a disagreement with the 0.20 sensitivity threshold principle (Speer, 2010). Reduced signal strength statistics of MAX was also discovered in $C$. atlantica (Esper et al., 2006). Our results show some significant correlations between MIN and climate data (Figure 5). To statistically improve climatic signal in P. nigra MIN chronologies, two approaches have been used so far: (1) where two proxies have the same dominant climate control, their combination enhances climatic signal and combining can be used to increase calibration correlation coefficients (Gagen et al., 2006; Stahle et al., 1991) and (2) climatic signal can be maximised with removing the relationship between MXD and TRW out of the maximum density series (Kirdyanov et al., 2007). We have not tested these two approaches, as this topics 
goes beyond the scope of this paper. However, for the future use of MBR method on the samples from the Balkan region, these two methods need to be taken into account as well as ecophysiological background of the tree-ring formation (which is also not discussed here). In particular, lignification of cell walls plays an important role in the climate-growth relationship as it influences the ring density (Gindl et al., 2000) and hence MBR readings.

\section{CONCLUSIONS} ZAKLJUČKI

With the introduction of the Minimum blue reflectance (blue intensity) method on P. nigra, we tested the climate signal embedded in tree-ring density. We discovered that latewood density (MIN) contains less strong climate signal than TRW, but the earlywood density (MAX) shows equal or stronger climate signal. The strongest correlation coefficient within density measurements was found between summed May-June precipitation and MAX $(r=0.64, p<0.001)$ and in width measurements between TRW and mean June-August temperature $(\mathrm{r}=-0.62, \mathrm{p}<0.001)$. Our results of climate signal in P. nigra width parameters of tree-rings are similar to previously published results, with no great differences observed.

\section{SUMMARY POVZETEK}

Na lastnosti branik, kot so širina celotne branike (TRW), širina ranega (EWW) in kasnega lesa (LWW) ter gostota ranega (MAX) in kasnega lesa (MIN), deluje več dejavnikov (Gričar in Čufar, 2008; Levanič, 1993). Z meritvami naštetih lastnosti branik lahko preučujemo vpliv klime na rast dreves. Raziskovalci so opazili, da ima MIN močnejši klimatski signal kot samo TRW (Cown in Parker, 1978; Levanič in sod., 2008; Schweingruber in sod., 1978). Sprva so gostotne profile branik merili s pomočjo rentgenskih žarkov, vendar je ta metoda draga in zahtevna (Schweingruber in sod., 1978). Za cenejšo pripravo vzorcev in pridobivanje rezultatov, primerljivih po metodi rentgenskih žarkov, so odkrili metodo odboja modrega spektra (Campbell in sod., 2011; McCarroll in sod., 2002), ki za svoje delovanje ne potrebuje nič drugega kot Soxhlet, kakovosten optični čitalec in osebni računalnik. Vrednost odboja svetlobe modrega spektra bo največja v ranem lesu, ki je svetlejši, najmanj odboja pa v kasnem lesu, ki je temnejši. Zaradi tega se MAX uporablja za oznako gostote ranega in MIN kasnega lesa. Prvi rezultati uporabe te metode opozarjajo, da vse iglaste drevesne vrste v MIN ne vsebujejo močnega klimatskega signala ter da je MAX tista, ki si zasluži pozornost (Esper in sod., 2006). Zato je pomembno, da preverimo drevesne vrste, ki dokazano vsebujejo klimatski signal v TRW, kot na primer črni bor (Pinus nigra Arnold) (Levanič in sod., 2012; Nicault in sod., 2008). Prve raziskave MIN na P. nigra iz Španije so pokazale, da se gostota, merjena z rentgenskimi žarki, ne odziva na klimatsko variabilnost (Dorado Liñán in sod., 2012). Toda ker črni bor raste na ekstremnih rastiščih in ima jasno izražen rani ter kasni les in je tudi predmet že mnogih uspešnih raziskav (Levanič in sod., 2012; Ogrin, 2005; Poljanšek in sod., 2012), smo želeli novo metodo merjenja gostote preskusiti na tej vrsti.

Izbrana drevesa so rastla v sestoju na apnenčasti podlagi na hribu Kojnik (780 m n.m.v.). Ta lokacija je bila izbrana na podlagi našega predvidevanja, da imajo drevesa s takega rastišča v parametrih branik klimatski signal. Območje je pod vplivom submediteranske klime (slika 1), vendar brez stroge periodičnosti v padavinskem režimu (Šraj in sod., 2008). Visoke temperature in pogoste poletne suše povzročajo višjo potencialno transpiracijo, kot je količina padavin v juliju in avgustu (Ogrin, 2005). Za potrebe analize vpliva klime na rast dreves smo uporabili vremensko postajo Kubed. Izbrana drevesa so bila vzorčena s $5 \mathrm{~mm}$ prirastnim svedrom, čeprav se po originalni metodi uporabljajo 10 ali $12 \mathrm{~mm}$ debeli vzorci (McCarroll in sod., 2002). Vzorci so bili vstavljeni v Soxhlet, kjer smo jih očistili smole. Aparat Soxhlet predstavlja povezavo bučke, iz katere s pomočjo gretja izhlapeva alkohol, ki se v povratnem hladilniku utekočini in steka v ekstraktor. Vzorci ležijo v ekstraktorju, kjer jih preliva alkohol, ki topi smolo. Ob doseženem zgornjem nivoju se alkohol prek cevke, imenovane natega, prelije nazaj v bučko in postopek se ponovi. Sledilo je sušenje, brušenje ter skeniranje vzorcev. Ob brušenju $\mathrm{z}$ vedno bolj finim brusnim papirjem smo opazili postopno vidno izboljšanje kakovosti površine vzorcev in prepoznali nevarnost, da se zaradi povečanega trenja med brusnim papirjem in vzorcem površina lesa prekomerno segreje, pri čemer prihaja do zažiganja površine lesa ter spremembe barve lesa. V prihodnje bi lahko vpliv brušenja odpravili z uporabo mikrotoma za prirastne vzorce (Gärtner in Nievergelt, 2010). Pred uporabo skenirne naprave smo njeno luč umerili z barvno lestvico. Zaradi boljše vidljivosti ozkih branik smo vzorce skenirali s 1600 dpi, čeprav je priporočljiva natančnost 1200 dpi (Babst in sod., 2009). Za merjenje parametrov branik smo uporabili program WinDENDRO ${ }^{\mathrm{TM}}$. Merili smo 
širino celotne branike ter širino in gostoto ranega ter kasnega lesa. Izmerjene časovne serije smo standardizirali s pomočjo kubičnih zlepkov (Cedilnik, 1991). To je s polinomom tretje stopnje določena krivulja, ki je zvezno odvedljiva in je približek pričakovani rasti dreves, brez vplivov okolja. Od celotne dolžine izračunanih standardnih kronologij (slika 3) smo za korelacijsko analizo s klimo uporabili le tisti del kronologij, ki je dosegel mejno vrednost EPS-količnika. Ta določa del kronologije, ki ima značilen skupen signal, primeren za analize vplivnih dejavnikov (Briffa in Jones, 1990). Ta vrednost je bila prva dosežena pri TRW v letu 1937, najkasneje pa pri MAX, šele v letu 1967 (preglednica 1). Slab skupen signal lahko pripišemo individualni rasti dreves v njihovem juvenilnem obdobju (Dorado Liñán in sod., 2012) in fiziološkim lastnostim lesa iz tega obdobja. Slabše ujemanje med drevesi $\mathrm{v}$ parametrih MIN in MAX bi lahko bile tudi posledice dejavnikov, kot so redčenja, lastnosti krošenj, genetske variabilnosti med drevesi (Jyske, 2008) ali individualnih odzivov dreves na sušne razmere (Martinez-Meier in sod., 2008).

Ugotovili smo pozitivno korelacijo med TRW, EWW ter LWW in marčevskimi temperaturami ter padavinami v juliju in avgustu, ter negativni vpliv julijskih, avgustovskih ter septembrskih temperatur (slika 4). Rezultati korelacij med padavinami oziroma temperaturami ter parametri širin so skladni S predhodnimi objavami raziskav rasti $P$. nigra $\mathrm{z}$ območja sub-mediteranske Slovenije (Ogrin, 1989; 2005; Srebotnjak, 1997). Poleg značilnih korelacij s klimatskimi parametri tekočega leta smo, podobno kot v Španiji (Dorado Liñán in sod., 2012), identificirali tudi značilne vplive klime predhodnega leta (slika 4). Višje poznopoletne temperature lahko vplivajo na podaljšano rast tkiv in porabo zalog hranil, prihranjenih za začetek prihodnje rastne sezone (Fritts, 1976). Na splošno so poletne padavine pozitivno korelirale z vsemi parametri širin, medtem ko je korelacija z gostoto slabše izražena. Najvišja korelacija med MIN in klimo je bila s povprečno temperaturo obdobja junij-avgust $(r=0.42)$, medtem ko je imela MAX še višjo korelacijo s količino padavin maj-junij ( $\mathrm{r}=0.64)$ (slika 5). Podobno največjo korelacijo med padavinami in gostoto ranega lesa so našli na cedri (Esper in sod., 2006); največja izračunana korelacija je bila med MAX in padavinami iz obdobja maj-junij. Pogoste dolgotrajne suše in vročinski valovi so lahko vzrok, da smo kljub slabi odzivnosti gostote branik P. nigra na klimo (Dorado Liñán in sod., 2012) lahko potrdili povezavo med MIN in povprečno temperaturo v obdobju junij-avgust (slika 5).
Z uporabo metode odboja modrega spektra smo preskušali vsebnost klimatskega signala $\mathrm{v}$ branikah dreves $P$. nigra. Odkrili smo, da gostota kasnega lesa (MIN) ne vsebuje tako močnega klimatskega signala kot širina celotne branike (TRW), je pa bil največji količnik izračunan med gostoto ranega lesa (MAX) in padavinami obdobja maj-junij ( $\mathrm{r}=0,64$, $\mathrm{p}<0,001)$. Ker je gostota branik manj pod vplivom lokalnih dejavnikov kot TRW (Levanič in sod., 2008), klimatski signal pa se lahko s posameznimi metodami še izboljša (Gagen in sod., 2006; Stahle in sod., 1991), bi lahko več prihodnjih raziskav namenili za preskus rekonstrukcij pretekle klime iz MAX.

\section{ACKNOWLEDGEMENTS ZAHVALE}

The authors would like to express warm thanks to Damjan Vatovec, Slovenian Forestry Service, for field support, Miha Humar for using Soxhlet during resin extraction, and Miha Demšar from the Slovenian Environmen Agency for providing us with meteorological data. Special thanks also to the team of dendrochronologists from the Swansea University; Danny McCarroll, Neil J. Loader, Iain Robertson and Giles H. F. Young for their help in the laboratory. This investigation was financed by student grant of Simon Poljanšek and EUFORINNO project (European Forest Research and Innovation, Grant Agreement No. 315982); EU 7th Frame Work Program - REGPOT 6/2012-12/2015.

\section{REFERENCES}

\section{VIRI}

Babst F., Frank D., Büntgen U., Nievergelt D., Esper J. 2009. Effect of sample preparation and scanning resolution on the Blue Reflectance of Picea abies. TRACE- Tree Rings in Archaeology, Climatology and Ecology, 7: 188-195.

Baillie M. G. L., Pilcher J. R. 1973. A simple cross-dating programme for tree-ring research. Tree-Ring Bulletin, 33: 7-14.

Briffa K. R., Jones P. D. 1990. Basic chronology statistics and assessment. $\mathrm{V}$ : Methods of dendrochronology: applications in the environmental sciences. Cook E. R. in sod. (ur.). (Methods of dendrochronology: applications in the environmental sciences, Dordrecht, Boston, London, Kluwer academic publishers: 137-152

Brus R. 2004. Drevesne vrste na slovenskem (Tree species on slovenian area; in slovenian). (ur.) Ljubljana, Mladinska založba: 399 str.

Campbell R., McCarroll D., Loader N. J., Grudd H., Robertson I. in sod. 2007. Blue intensity in Pinus sylvestris tree-rings: developing a new palaeoclimate proxy. The Holocene, 17, 6: 821-828.

Campbell R., McCarroll D., Robertson I., Loader N. J., Grudd H. in sod. 2011. Blue Intensity In Pinus sylvestris Tree Rings: A Manual for A New Palaeoclimate Proxy. Tree-Ring Research, 67, 2: 127-134.

Cedilnik A. 1991. Aproksimacija rastnih funkcij s kubičnimi zlepki. Zbornik gozdarstva in lesarstva, 37: 117-123. 
Cook E. R. 1985. Time series analysis approach to tree ring standardization: Dissertation. (University of Arizona). Tucson: $171 \mathrm{str}$.

Cown D. J., Parker M. L. 1978. Comparison of annual ring density profiles in hardwoods and softwoods by X-ray densitometry. Canadian Journal of Forest Research, 8, 4: 442-449.

Dorado Liñán I., Gutiérrez E., Heinrich I., Andreu-Hayles L., Muntán E. in sod. 2012. Age effects and climate response in trees: a multi-proxy treering test in old-growth life stages. European Journal of Forest Research, 131, 4: 933-944.

Eckstein D., Bauch J. 1969. Beitrag zur Rationalisierung eines dendrochronologischen Verfahrens und zur Analyse seiner Aussagesicherheit. Forstwissenschaftliches Centralblatt, 88, 4: 230-250

Esper J., Büntgen U., Frank D., Nievergelt D., Nievergelt D. in sod. 2006. Multiple tree-ring parameters from Atlas cedar (Morocco) and their climatic signal. Tree rings in archaeology, Climatology, and Ecology (TRACE), 4: 46-55.

Fritts H. C. 1976. Tree rings and climate. (ur.) London, New York, San Francisco, Academic Press: 567 str.

Fritts H. C., Swetnam T. W. 1998. Dendroecology: A tool for evaluating variations in past and present forest environments. $\mathrm{V}$ : Advances in ecological research. Begon M. in sod. (ur.). Advances in ecological research, 111-154

Gagen M., McCarroll D., Edouard J.-L. 2006. Combining Ring Width, Density and Stable Carbon Isotope Proxies to Enhance the Climate Signal in Tree-Rings: An Example from the Southern French Alps. Climatic Change, 78, 2: 363-379.

Gärtner H., Nievergelt D. 2010. The core-microtome: A new tool for surface preparation on cores and time series analysis of varying cell parameters. Dendrochronologia, 28, 2: 85-92.

Gindl W., Grabner M., Wimmer R. 2000. The influence of temperature on latewood lignin content in treeline Norway spruce compared with maximum density and ring width. Trees - Structure and Function, 14: 409-414.

Gričar J., Čufar K. 2008. Seasonal dynamics of phloem and xylem formation in silver fir and Norway spruce as affected by drought. Russian Journal of Plant Physiology, 55, 4: 538-543.

Jurc M. 2001. Vpliv požarov na entomofavno - predvsem subkortikalno, v monokulturah črnega bora (Pinus nigra ARN.) na slovenskem Krasu. Zbornik gozdarstva in lesarstva, 66: 25 .

Jyske T. 2008. The effects of thinning and fertilisation on wood and tracheid properties of Norway spruce (Picea abies) - the results of long-term experiments: (University of Helsinki). Helsinki: 59 str.

Kirdyanov A., Vaganov E., Hughes M. 2007. Separating the climatic signal from tree-ring width and maximum latewood density records. Trees Structure and Function, 21, 1: 37-44.

Koga S., Zhang S. Y. 2004. Inter-tree and intra-tree variations in ring width and wood density components in balsam fir (Abies balsamea). Wood Science and Technology, 38, 2: 149-162.

Kranjc A. 2009. History of Deforestation and Reforestation in the Dinaric Karst. Geographical Research, 47, 1: 15-23.

Levanič T. 1993. Effects of hydromelioration on diameter growth and increment of black alder, ash and oak in Slovene Prekmurje. Zbornik gozdarstva in lesarstva, 42: 7-65.

Levanič T., Gričar J., Gagen M., Jalkanen R., Loader N. in sod. 2008. The climate sensitivity of Norway spruce (Picea abies (L.) Karst.) in the southeastern European Alps. Trees - Structure and Function, 23, 1: 169180 .
Levanič T., Popa I., Poljanšek S., Nechita C. 2012. A 323-year long reconstruction of drought for SW Romania based on black pine (Pinus nigra) tree-ring widths. International Journal of Biometeorology, 1-12.

Martinez-Meier A., Sanchez L., Pastorino M., Gallo L., Rozenberg P. 2008. What is hot in tree rings? The wood density of surviving Douglas-firs to the 2003 drought and heat wave. Forest Ecology and Management, 256, 4: 837-843.

McCarroll D., Pettigrew E., Luckman A., Guibal F., Edouard J. L. 2002. Blue Reflectance Provides a Surrogate for Latewood Density of HighLatitude Pine Tree Rings. Arctic, Antarctic, and Alpine Research, 34, 4: 450-453.

Melvin T. M., Briffa K. R. 2008. A “signal-free” approach to dendroclimatic standardisation. Dendrochronologia, 26, 2: 71-86.

Nicault A., Alleaume S., Brewer S., Carrer M., Nola P. in sod. 2008. Mediterranean drought fluctuation during the last 500 years based on tree-ring data. Climate Dynamics, 31, 2: 227-245.

Ogrin D. 1989. Vpliv padavinskih in temperaturnih razmer na širino letnic črnih borov (Pinus nigra) v submediteranski Sloveniji. Dela, 6: 10.

Ogrin D. 1992. Vpliv padavin in temperatur na debelinski prirast črnih borov in hrastov gradnov v Koprskem primorju in na Krasu. Annales : anali Koprskega primorja in bližnjih pokrajin = annali del Litorale capodistriano e delle regioni vicine, 2, 2: 9.

Ogrin D. 2005. Tree rings and climate in submediterranean Slovenia. TRACE 2005 ,

Parker M. L., Bunce H. W. F., Smith J. H. G. 1976. The use of X-ray densitometry to measure the effects of air-pollution on tree growth near Kitimat, British Columbia. (Internationale Tagung uber die Luftverunreinigung und Forstwirtschaft, IUFRO (ur.) Marianske Lazne, Tschechoslowakei., Tagungsbericht: 185-204 str.

Polge H. 1963. Une nouvelle methode de determination de la texture du bois: l'analyse densitometrique de cliches radiographiques. Annales des Sciences Forestieres, 20, 4: 531-581.

Poljanšek S., Ballian D., Nagel T. A., Levanič T. 2012. A 435-Year-Long European Black Pine (Pinus nigra) Chronology for the Central-Western Balkan Region. Tree-Ring Research, 68, 1: 31-44.

Schweingruber F. H., Fritts H. C., Bräker O. U., Drew L. G., Schär E. 1978. The X-ray technique as applied to dendrochronology. Tree Ring Bulletin, 38: 61-91.

Speer J. H. 2010. Fundamentals of tree-ring research. (ur.) The University of Arizona Press.: 324 str.

Srebotnjak K. 1997. Dendroekološka analiza črnega bora (Pinus nigra Arnold) na Divaško Komenskem Krasu: (Univerza v Ljubljani). Ljubljana: 80 str.

Stahle D. W., Cleaveland M. K., Cerveny R. S. 1991. Tree-ring reconstructed sunshine duration over central USA. International Journal of Climatology, 11, 3: 285-295.

Šraj M., Brilly M., Mikoš M. 2008. Rainfall interception by two deciduous Mediterranean forests of contrasting stature in Slovenia. Agricultural and Forest Meteorology, 148, 1: 121-134.

Tomazello M., Brazolin S., Chagas M. P., Oliveira J. T. S., Ballarin A. W. 2008. Application of $\mathrm{x}$-ray techique in nondestructive evaluation of eucalypt wood. Ciencia y tecnologia, 10, 2: 139-149.

Vidaković M. 1991. Conifers: morphology and variation. (ur.) Zagreb, Grafički zavod Hrvatske: 754 str.

Wilmking M., Hallinger M., Van Bogaert R., Kyncl T., Babst F. in sod. 2012. Continuously missing outer rings in woody plants at their distributional margins. Dendrochronologia, 30, 3: 213-222.. 